\title{
Wimmer Ágnes
}

\section{Az üzleti kapcsolatok értékelése}

\section{A cikk az üzleti teljesítménymérés és teljesítménymenedzsment szemszögéből}

vizsgálja az üzleti kapcsolatokat. Hogyan befolyásolhatják az üzleti kapcsolatok az

üzleti teljesítményt? Milyen információkra van szükségünk az üzleti kapcsolatok

értékeléséhez, fejlesztéséhez, menedzseléséhez? Hogyan támogatják mindezen

tevékenységeket a teljesítménymérés és teljesítménymenedzsment rendelkezésre

álló megközelítései és módszerei? ${ }^{2}$

Egy üzleti vállalkozás müködése során különböző érintettekkel, partnerekkel kerül kapcsolatba, így többek között az ügyfelekkel, a beszállítókkal, az értékesítési csatornákban a közvetítökkel, az alvállalkozókkal, a különböző szolgáltatókkal, a fejlesztésekben együttmüködő vállalatokkal stb. E kapcsolatok az esetek többségében szervezetek, vállalatok között jönnek létre, kivéve az egyéni ügyfelekkel, vevőkkel való kapcsolatokat. Kutatásunkban az üzleti kapcsolatokat az üzleti vállalkozások érintettjeikkel való kapcsolataiként értelmezzük. Ugyanakkor érdemes megjegyeznünk, hogy az üzleti kapcsolatok gondolatköre és szemléletmódja nemcsak üzleti vállalkozások, hanem bármely más szervezet, intézmény partnereivel, érintettjeivel való kapcsolataira is kiterjeszthető, alkalmazható. A következőkben elsősorban a vevői és a szállítói kapcsolatokra koncentrálunk, azonban a bemutatott eszközök és szemléletmód más érintettekkel kapcsolatban is felhasználható.

A cikk először az üzleti kapcsolatok üzleti teljesítményt befolyásoló szerepével foglalkozik. A vállalati kapcsolatok jellemzéséhez javasolt elemzési keretben megkülönböztetjük a partner teljesítményének és a kapcsolatnak az értékelését. A kapcsolatra ható tényezők között kiemeljük a partnerek hozzáállását és az együttmüködés jellemzőit, a realizált kapcsolatok jellemzésekor felhívjuk a figyelmet az objektív és a szubjektív elemek jelentőségére. Vállalati szemszögböl az egyedi partnerek értékelése mellett a partnerportfólió értékelése is helyet kap. A cikk második részében azt vizsgáljuk, hogy az üzleti teljesítménymérés, teljesítménymenedzsment szemléletmódja és eszközei mennyiben támogatják, támogathatják az üzleti kapcsolatok értékelését, fejlesztését, menedzselését? Ennek áttekintésére elsőként a teljesítménymérési módszerek elmúlt évtizedekben megfigyelhető fejlődési irányai, s a hozzájuk kapcsolódó eszközök értékelése ad keretet. Az utolsó rész a vevő-szállító

\footnotetext{
${ }^{2}$ A cikk az Üzleti kapcsolatok értékteremtő szerepe c. OTKA F037789 sz. kutatás keretében készült, a 2003 decemberében a BKÁE (azóta Budapesti Corvinus Egyetem) Vállalatgazdaságtan tanszéke által szervezett „Üzleti kapcsolatok és értékteremtés" konferencián elhangzott „Teljesítménymérés: az üzleti kapcsolatok értékelése, fejlesztése, menedzsmentje" címü előadás továbbfejlesztett változata.
} 
kapcsolatok értékelésének elterjedt megközelítéséire és hiányosságaira hívja fel a figyelmet.

Az üzleti teljesítménymérés és teljesítménymenedzsment szemszögéböl, annak eszköztárát, szemléletmódját elemezve vizsgálódunk, középpontba állítva a vállalati teljesítményt (tehát nem a kapcsolati hálók vagy ellátási láncok teljesítményét kutatjuk). A fö kérdés: hogyan állíthatók az üzleti kapcsolatok az eredményes és hatékony vállalati müködés szolgálatába, s az üzleti kapcsolatokra vonatkozó információk hogyan támogathatják a teljesítmény javítását ?

\section{Az üzleti teljesítmény és az üzleti kapcsolatok}

Egy vállalat tevékenységét és eredményességét, versenyképességét jelentős mértékben befolyásolja, hogy hogyan teljesítenek az ellátási láncban előtte szereplők, vagyis a vállalat beszállítói, üzleti partnerei. Hasonlóképpen meghatározó, hogy hogyan, milyen közvetítőkön keresztül jut el a termék, a szolgáltatás a végső felhasználóhoz, a fogyasztóhoz. Mind a partnerek teljesítménye, mind a velük való kapcsolat jellemzői jelentősen befolyásolhatják a vállalatok hatékony és gazdaságos müködését. Ezáltal értéket képviselhetnek a számukra, értékteremtő tényezőkké válhatnak, vagy éppen ellenkezőleg, értékrombolóak is lehetnek. ${ }^{3} \mathrm{Az}$ értékteremtés vagy éppen rombolás következményei kihatnak a vállalat piaci értékére, a tulajdonosok számára teremtett értékre is. ${ }^{4}$

Az üzleti teljesítmény megítélése, s ezáltal a teljesítménymérés hagyományosan a (belső) vállalati tevékenységekre, illetve azok eredményére fókuszál. Manapság azonban egyre elfogadottabb, hogy ellátási láncok, sőt ellátási hálók, hálózatok versenye zajlik az üzleti életben. Hiába a kiváló egyéni teljesítmény, ha egy vállalat üzleti partnerei, a beszállítói, az alvállalkozói, termékeinek vagy szolgáltatásainak közvetítői, az ellátási (értékesítési) lánc más kapcsolódó szereplői nem teljesítenek megfelelően. Ez a függőség nemcsak a beszállító vagy közvetítő partnerekre vonatkozhat, hanem a keresleti oldalra is: speciális termékek/szolgáltatások, s nagy kapcsolatspecifikus befektetések esetében a vevők üzleti problémáinak tovagyürüző hatása is okozhat válságot. Mindez azt jelzi, hogy a vállalkozások sikerét nagy mértékben befolyásolják üzleti partnereinek teljesitményei, illetve az üzleti partnerekkel való kapcsolat jellemzői. (1. ábra)

\section{1. ábra}

\section{Az üzleti kapcsolatok értékelésének elemei}

\footnotetext{
${ }^{3}$ Részletesebben lásd Wimmer - Mandják, 2003.

${ }^{4}$ Az üzleti kapcsolatok pénzügyi értékelési lehetőségeiről, a vállalati értékre gyakorolt hatás számszerüsítéséről lásd Juhász (2005).
} 


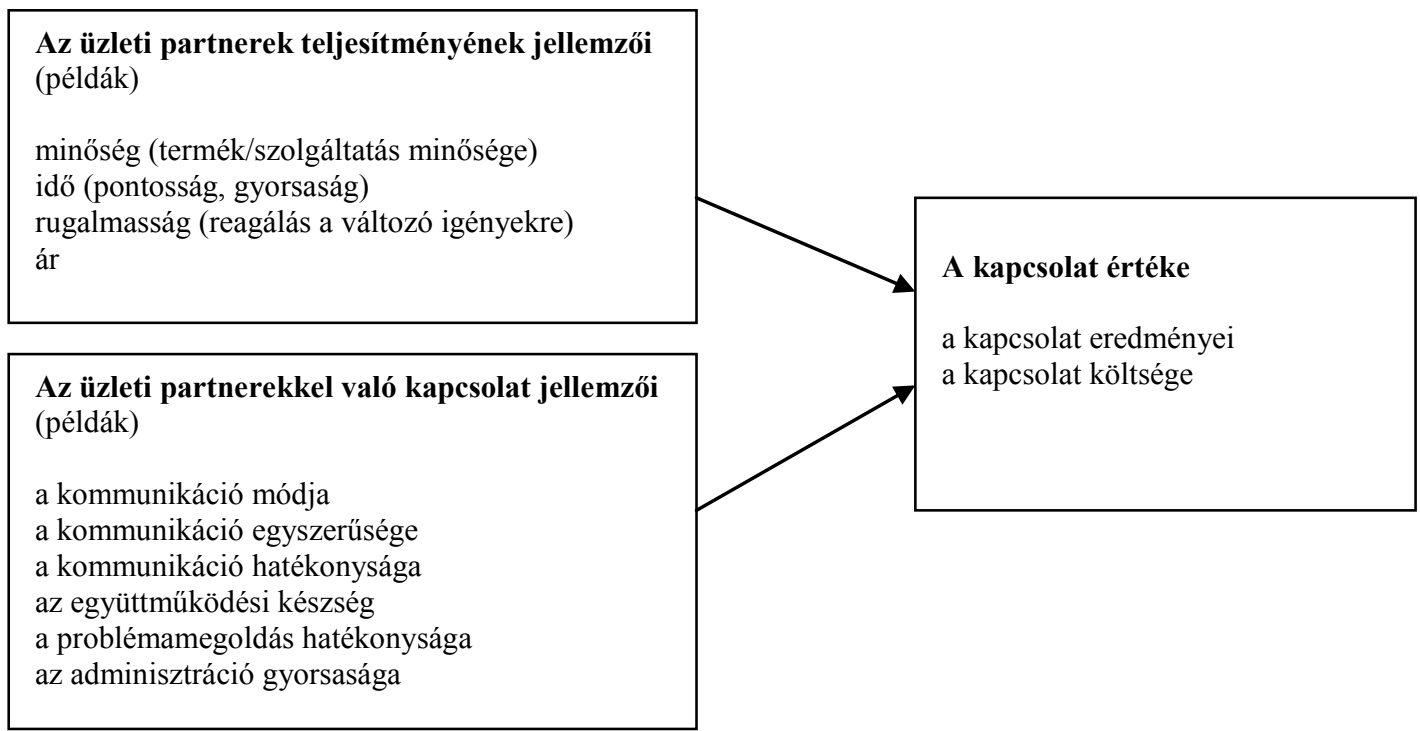

Érdemes tehát figyelemmel lenni mind a partnerek, mind a kapcsolat értékelésére. $A z$ üzleti partnerek teljesitménye a klasszikus versenytényezőkön keresztül ítélhető meg (pl. az elvárt minőség nyújtása, a határidők betartása, a rugalmasság, az alacsony költségek stb.). A kapcsolat fö jellemzöi az együttmüködés sikerén mérhetők, beleértve az erre való készséget, s ennek gyakorlati megvalósulását. A kapcsolat további fontos jellemzője az érintettek kölcsönös elégedettsége: ez egy gyakran elfeledett szempont, azonban a fejlesztések fontos mozgatórugója lehet. Az érintettek elégedettségét a partnerek teljesítményének és a velük való kapcsolatnak az értékelése is befolyásolhatja. Két hasonló teljesítményt nyújtó (azonos minőségü terméket, azonos árakon kínáló, hasonlóan rugalmas stb.) beszállító esetén például értékesebb (s kisebb teljes költséggel jár) az a kapcsolat, ahol egyszerübb a kommunikáció, gyorsabb az adminisztráció, azonnal felveszik a telefont, gyorsan visszaigazolják a megrendeléseket, nem kell hosszasan magyarázkodni, hogy pontosan mit is szeretne a megrendelö stb. A kapcsolatok értékelésében is a teljesköltség-megközelítés lehet célravezető.

Az üzleti partnerek (vevők, szállítók), illetve vállalatközi kapcsolatok jellemzésében az elözetes elvárásoktól az együttmüködés realizálásán keresztül az együttmüködés eredményének értékeléséig főként a következő jellemzők érdemelnek figyelmet:

- Vizsgálhatjuk az érintettek hozzáállását, a kapcsolatokra vonatkozó szemléletmódot, s előzetes elvárásokat: Milyen célokat, elvárásokatat fogalmaznak meg implicit vagy explicit módon a partnerek? Mi alapján értékelik a kapcsolatokat, milyen fejlesztési célokat tüznek ki stb.

- Az együttmüködés jellemzői, szintjei is fontos mutatói e kapcsolatoknak: Milyen az információmegosztás, a kommunikáció módja a partnerek között, milyen területekre terjed ez ki, milyen gyakori? Milyen együttmüködési formák müködnek, milyen időtávokban gondolkodnak a résztvevők, mennyire támasztják szerződésekkel alá az elvárásokat? Milyen az integráció mértéke, milyen beruházások történnek a kapcsolatokba?

- A kapcsolatokat befolyásoló tényezők között természetesen a közvetlenül nem az üzleti kapcsolatokhoz kötődő további jellemzők is szerepelnek, mint például a különböző érintettek elvárásai és tevékenysége, az iparági környezet és az általános üzleti környezet jellemzői stb. 
- A „,realizált”, müködő kapcsolatok (illetve a partnerek teljesitményének) jellemzése történhet mérhető, objektív adatokkal, mint például a kapcsolatok száma, ezek súlya különböző mennyiségi jellemzők alapján (pl. az egyes partnerekkel való forgalom mennyisége, s ennek részesedése az összforgalomból). Hasonlóan fontosak lehetnek a szubjektív jellemzők, a kapcsolatok sikerének értékelése, az elégedettség, a bizalom, s a siker és az értékteremtés minősítése a partnerek részéröl.

A kapcsolatokhoz való hozzáállás (szemléletmód) és az együttmüködés kialakított formái befolyásolják a realizált kapcsolatok jellemzőit, s e kapcsolatokban az érintett partnerek által nyújtott teljesítményt. E teljesítmény és az együttmüködés objektív és szubjektív elemeinek megítélése határozza meg, hogy miként értékelik a kapcsolatot az érintettek. (E tényezőket foglalja össze a 2. ábra.) 


\section{2. ábra}

A vállalatközi kapcsolatok értékelésére ható tényezők

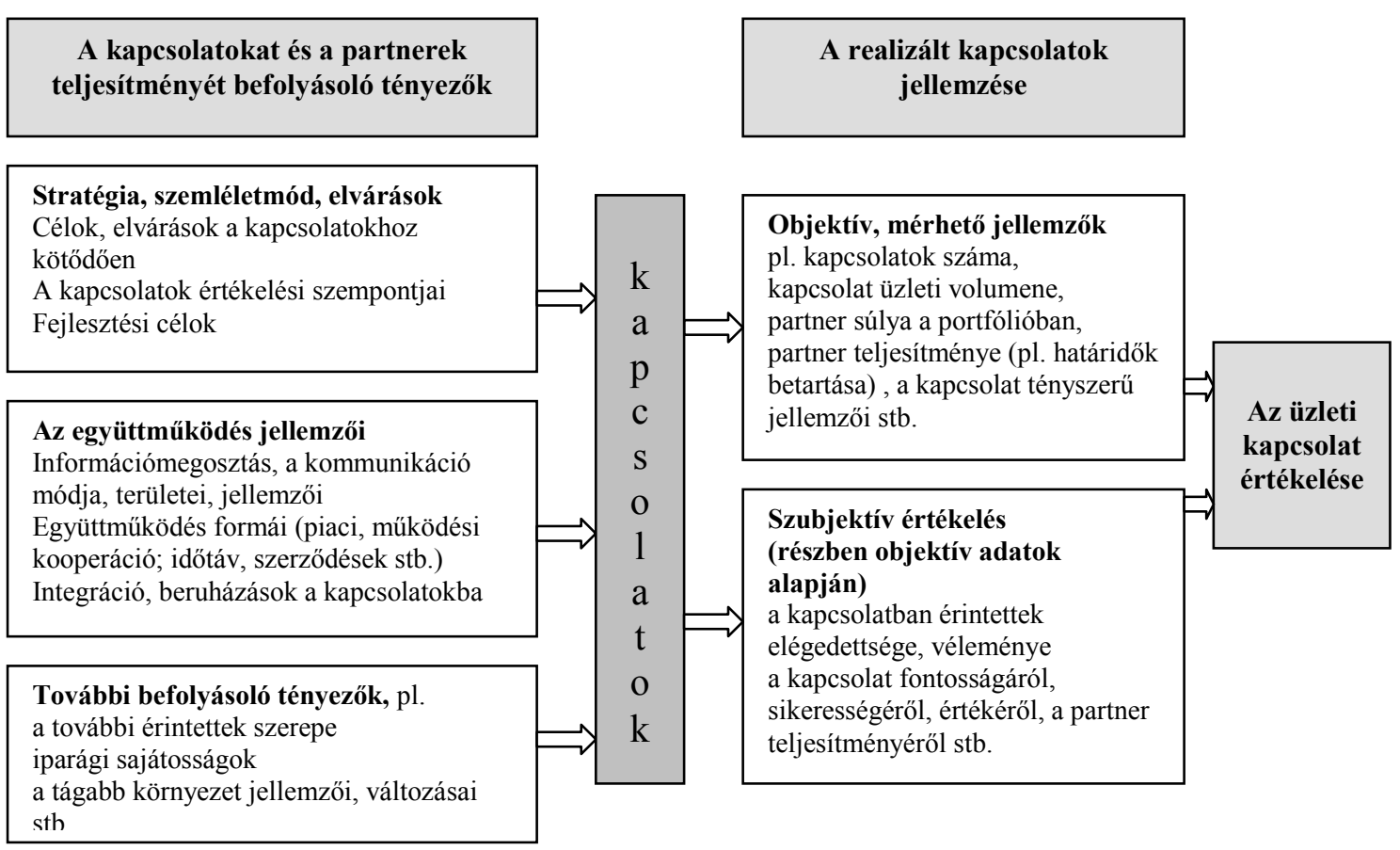

Vállalati szempontból a partnerek teljesítményének, illetve a velük való kapcsolat jellemzőinek egyenkénti értékelése mellett kiemelt fontosságú a kapcsolati portfólió értékelése. Egy-egy vállalat általában sok partnerrel áll kapcsolatban, így nemcsak az egyes partnereket kell(ene) megismernie, értékelnie, s menedzselni a velük való kapcsolatot, hanem át kell(ene) látnia és kezelnie kell(ene) a partnerportfóliót is. Ahogyan a termékkínálat időröl időre felülvizsgálatra szorul, különböző mennyiségi és minőségi jellemzők alapján, hasonlóképpen a vevői, illetve a szállítói portfólió menedzselése, kézben tartása is fontos feladat.

A 3. ábra az üzleti kapcsolatok értékelésének módjára mutat példákat az értékelés területe (a partner teljesítménye vagy a kapcsolat jellemzőinek és sikerének értékelése) és az értékelés szintje (egyedi partner, illetve a partnerportfólió értékelése) szerinti bontásban. 


\section{3. ábra}

Az üzleti kapcsolatok értékelésének szintjei és területei (példák)

\begin{tabular}{|c|c|c|}
\hline Terület & Egyedi partnerek szintjén & Partner- (kapcsolat-) portfólió szintjén \\
\hline $\begin{array}{l}\text { Az üzleti partner } \\
\text { teljesítménye }\end{array}$ & $\begin{array}{c}\text { Értékesített, illetve vásárolt } \\
\text { mennyiség } \\
\text { Árrés, realizált fedezet, illetve a } \\
\text { beszerzési árak szintje, változása } \\
\text {---------- } \\
\text { Termékek / szolgáltatások } \\
\text { minősége } \\
\text { Határidők betartása } \\
\text { Rugalmasság }\end{array}$ & $\begin{array}{l}\text { ABC (Pareto) elemzés a partnerre jellemző } \\
\text { „tények” alapján (pl. értékesített, illetve } \\
\text { vásárolt mennyiség, v. az ügyfelek } \\
\text { kiszolgálásának jövedelmezősége) } \\
\text { Csoportok képzése, partnerkategóriák } \\
\text { kialakítása a partnerek jellemzői (pl. } \\
\text { vállalatméret, súly) és teljesítménye (pl. } \\
\text { minőség) alapján }\end{array}$ \\
\hline $\begin{array}{c}\text { Az üzleti } \\
\text { partnerrel való } \\
\text { kapcsolat jellemzői }\end{array}$ & $\begin{array}{c}\text { Kommunikáció, kooperáció, } \\
\text { integráció, közös projektek } \\
\text {-------------- } \\
\text { Kölcsönös elégedettség szintje }\end{array}$ & $\begin{array}{l}\text { Csoportok képzése, partner-kategóriák } \\
\text { kialakítása a partnerkapcsolat jellemzői, } \\
\text { illetve az elégedettség alapján }\end{array}$ \\
\hline
\end{tabular}

A kapcsolati portfólió értékelése is történhet a puszta „tények”, objektív adatok alapján, mint például az összértékesítésből (illetve a beszerzésből) való részesedés. A mennyiségi jellemzők mellett a stratégiai szempontok szerepe is jelentős - ezek figyelembevételével több portfólióelemzési megközelítés is ismert a stratégia és a beszerzés terén. Ilyen pl. Bensaou (1999) vevö-szállító kapcsolatokat a specifikus befektetések nagysága alapján tipizáló mátrixa (részletesebben lásd Pecze, 2005) vagy a beszerzés területén ismert Kraljic-mátrix (Kraljic, 1983), mely a termékeket rendszerezi a beszerzés fontossága és kockázata alapján.

A továbbiakban az üzleti teljesítménymérés eszköztárát vizsgáljuk abból a szempontból, hogy a rendelkezésre álló eszközök - különös tekintettel az elmúlt egy-két évtizedben bekövetkezett fejlödésre - mennyiben alkalmasak az üzleti kapcsolatok fejlesztésének támogatására.

\section{A teljesítménymérés eszköztára az üzleti kapcsolatok szemszögéböl}

Mire is szolgál a teljesítménymérés? Andy Neely és munkatársai (2004) megfogalmazása szerint az üzleti teljesítménymérés feladata ,a megalapozott döntések és cselekvések támogatása, azáltal, hogy a megfelelő adatok összegyüjtésével, feldolgozásával, rendszerezésével, elemzésével és értelmezésével számszerüsíti a múltbeli cselekedetek hatékonyságát és eredményességét”.

A vállalatok teljesítménymérési gyakorlatát ért kritikák a 80-as években főként a pénzügyi információk dominanciáját, sőt szinte kizárólagosságát emelték ki. Gyakran említett probléma volt, hogy kevés az információ a kiszolgálási színvonalról, illetve a müködéshez kapcsolódó teljesítményről, így a rendszeresen nyomon követhető adatok, 
információk a pénzügyi eredményesség utólagos regisztrálására alkalmasak, de nem szolgálják megfelelően a döntéshozók munkáját. A teljesítménymérés eszköztárában és szemléletmódjában az elmúlt évtizedekben bekövetkezett fejlődéssel az üzleti partnerekhez, s az üzleti kapcsolatokhoz kötődően is megfigyelhető elörelépés. ${ }^{5}$

A költséggazdálkodás és az üzleti kapcsolatok értékelése

A költséggazdálkodási módszerek fejlődésének egyik kulcsa a relevánsabb, az okokozati kapcsolatokat figyelembe vevő, a működési folyamatokhoz kapcsolódó megközelítések kifejlesztése, terjedése a nyolcvanas évek végétöl, a kilencvenes évek elejétől. A vevő-szállító kapcsolatokhoz kötődően két területet érdemes kiemelnünk:

A tevékenységalapú költségszámítás és -menedzsment ${ }^{6}$ nemcsak a termékek vagy szolgáltatások költségeinek pontosabb kalkulációját tüzi ki célul, hanem a folyamatok elemzésére alkalmas - s ezáltal fejlesztésüket támogató - információkkal is szolgál. Ez az elemzés kiterjeszthető a vállalat határain túlra, s az ügyfelek jövedelmezöségének elemzését vagy a szállitókkal való kapcsolattartás költségeinek mérését is segítheti. A gyakorlati példák főként a vevők elemzéséhez kapcsolódnak: az új költségszámítási rendszer bevezetését követően gyakran kiderül, hogy a vevők egy részének kiszolgálása veszteséget hoz a cégnek. A kiszolgálás költségeinek átláthatóvá tétele segítheti a kapcsolat (vagy a szokásos tranzakciók) átalakítását nyereségessé, illetve végső esetben a kapcsolat megszüntetésére is ösztönözhet. A beszállítói oldalon a „tulajdonlás teljes költsége" (TCO) koncepció alkalmazásának támogatására elvileg kiválóan alkalmas a tevékenységalapú költségszámítás, a gyakorlatban azonban sokszor nem kapcsolódnak össze e rendszerek (Ellram, 1995).

Az ún. japán költséggazdálkodási technikák, mint például az életciklus-költségszámítás, a célköltségszámítás vagy a kaizen költségmenedzsment ${ }^{7}$ elsődlegesen nem a kalkulációra, hanem a fejlesztésre, s a költségek csökkentésére helyezik a hangsúlyt. E megközelítések valamennyien építenek az üzleti partnerek bevonására, a velük való intenzív kommunikációra, az elvárások közvetítésre, így elvileg az üzleti kapcsolat kezelését, fejlesztését, a cégek közötti együttmüködést is támogatják.

\section{Teljesitménymutatók és az üzleti kapcsolatok értékelése}

Az operatív, a müködéshez kapcsolódó mutatók használata kibővült az elmúlt évtizedekben a hagyományos pénzügyi mutatók mellett mind a nemzetközi, mind a hazai kutatási eredmények szerint. A belső információforrások mellett a külső forrásból származó adatok, illetve a véleményen alapuló, szubjektív információk felhasználása is nagyobb figyelmet kap. Mindezek a tendenciák kedvezőek a vevőkhöz, illetve a szállítókhoz kapcsolódó teljesítményjellemzők rendszeres nyomon követéséhez, s az üzleti partnerek véleményének becsatornázásához.

A teljesítménymutatók szélesebb körének alkalmazása ugyanakkor még nem jelenti azt, hogy a döntéshozók, felhasználók által észlelt fontosságuknak, hasznosságuknak megfelelő súlyt kapnának. A szakirodalomban definiált teljesítménymérési ,rések” (Dixon et al., 1990; Schmenner - Vollmann, 1994) - vagyis a fontosnak minősített, de

\footnotetext{
${ }^{5}$ A kritikák összefoglalását lásd például Wimmer (2004). A különböző teljesítménymérési módszerek részletes bemutatása nem célja a tanulmánynak, ezekről részletesebben lásd pl. Wimmer (2002), valamint az e tanulmányban hivatkozott forrásokat.

${ }^{6}$ Magyarul lásd pl. Kaplan - Cooper (1998) vagy Kaplan - Atkinson (2003) 4-5. fejezet.

${ }^{7}$ Lásd pl. Cooper (1996) vagy magyarul Kaplan - Atkinson (2003) 6. fejezet.
} 
nem használt mutatók - gyakran éppen a vevőkiszolgálás jellemzőihez, s az ügyfelek elégedettségéhez kapcsolódnak. Ezt a hazai versenyképesség-kutatás eredményei is megerősítik (lásd pl. Chikán - Czakó - Zoltayné (szerk.), 2002).

A teljesítményméréssel foglalkozó korábbi kutatásunk egyik következtetése az volt, hogy a hazai vállalatok teljesítménymérési gyakorlatában az üzleti partnerekkel folytatott kommunikáció gyakran nem támogatja megfelelően a stratégiai célok elérését (Wimmer - Pecze, 2001; Wimmer, 2000). A vállalatok által fontosnak tartott versenytényezők, fejlesztési célok gyakran nem jelennek meg a szállítóértékelésben, illetve nem kommunikálják megfelelően a beszállítók, üzleti partnerek felé az elvárásokat. Hasonlóképpen a vevőktől származó visszacsatolások kezelése is problémás. A versenyképesség-kutatás 1999-es felmérésének eredményei azt jelzik, hogy a vállalatok teljesítménymérési gyakorlatában az egyik legnagyobb „rés” a vevői elégedettséghez kapcsolódik. A vállalatok egyre inkább felismerik a jelentőségét, ugyanakkor viszonylag kevesen gyüjtik a kapcsolódó információkat. A vevői elégedettség mérése a vállalatvezetők által észlelt fontosságához képest kevéssé jelenik meg a teljesítménymérési gyakorlatban, vagyis ,alulmérésről” van szó (Wimmer, 2000; Czakó - Wimmer - Zoltayné (szerk.), 2000).

\section{Az üzleti kapcsolatok megjelenése az átfogó teljesitménymérési keretekben}

A teljesítménymérési gyakorlatot sok kritika érte az egyoldalúság, a stratégiai szemlélet hiánya, az összefüggések, illetve az oksági kapcsolatok figyelembevételének mellőzése miatt. Ezekre a felvetésekre reagálva számos ún. integrált, stratégiai teljesitménymérési keret született, melyek több dimenzióban ragadják meg a teljesítményt, s igyekeznek kapcsolatot teremteni a stratégiai célok és a megvalósításukat segítö müködési jellemzők, folyamatok között. E keretek közül az egyik legismertebb a balanced scorecard, vagy más néven a kiegyensúlyozott stratégiai mutatószámok rendszere ${ }^{8}$, mely négy nézőpont - közte a vevők nézőpontja (,Milyenek vagyunk az ügyfeleink szemében?") - köré javasolja csoportosítani a rendszeresen figyelt teljesítménymutatókat. Ezeket a stratégiából kell levezetni, megfogalmazva a célokat, az eredménymutatókat, s az elérésüket befolyásoló teljesítményokozókat.

Egy korábbi, de kevéssé divatossá vált keretet ad a SMART (Strategic Measurement Analysis and Reporting Technique $)^{9}$ nyolcvanas évek végén kifejlesztett teljesítménypiramisa, mely a teljesítmény piaci és pénzügyi jellemzőiből indul ki, s kapcsolja ezeket az alapvető versenytényezőkhöz, s a vállalati tevékenységekhez. A piramis köztes szintjének kiemelt jellemzői a fogyasztói elégedettség, a rugalmasság és a termelékenység.

Mindkét keretben a pénzügyi eredményességet befolyásoló tényezőként megjelenik a piaci teljesítmény, s ehhez kapcsolódóan a vevő, a fogyasztó elégedettsége. Nincs szó ugyanakkor az ellátási láncban megelőző szereplőkről. A balanced scorecardot ért egyik gyakori kritika éppen a szállítók, mint fontos partnerek, s az üzleti teljesítményt befolyásoló szereplők mellőzését emeli ki. Noha ez védhető azzal, hogy a müködési folyamatok nézőpontban megjeleníthető a szállítói teljesítmény is, illetve azzal, hogy a

\footnotetext{
${ }^{8}$ Magyarul lásd pl. Kaplan - Norton (1998).

${ }^{9}$ Részletesebben lásd pl. Cross - Lynch (1989) vagy magyarul Chikán - Demeter (szerk.) (1997: 3.5.1. fejezet).
} 
javasolt négy nézőpont nem egyenruha, csupán keret, a lényeg nem változik: e „kiegyensúlyozott” rendszer sem kiegyensúlyozott a folyamatok input, illetve output oldalán megjelenő partnerek kezelésében.

Az integrált keretek között érdemes említést tennünk a minőségmenedzsment eszközeiről is - bár ezek nem tartoznak szorosan a vezetői számvitel eszköztárába, ma már gyakran a teljesítménymérési és teljesítménymenedzsment-rendszerek részeként jelennek meg. Megjelennek az üzleti partnerek a nemzeti minöségi dijak és kiválóság dijak kritériumrendszerében a vizsgálandó adottságok és az eredmények csoportjában is. A magyar Nemzeti minőségi díj modellben - mely az EFQM által kidolgozott Európai Kiválósági modellre épül - az adottságcsoporton belül szerepel a partnerkapcsolatok és erőforrások alkritérium, míg az eredmények csoporton belül a legnagyobb súllyal a vevői elégedettség. ${ }^{10}$

\section{A teljesitménymérés újabb válsága - a böség zavara?}

Az előbbiekben áttekintett teljesítménymérési módszerek is jelzik, hogy a 90-es évekre az elméletalkotók és a vállalati gyakorlat is számos ponton túllépett az előző évtized végén megfogalmazott válságtüneteken - bár az eszköztár rendelkezésre állása még nem jelenti az alkalmazását, $\mathrm{s}$ főként hasznosítást is egyben. Időközben az információtechnológia fejlődésével az adatokhoz, információkhoz való hozzáférés, $\mathrm{s}$ ezek feldolgozása sokkal könnyebbé, egyszerübbé vált. A mai integrált vállalatirányítási (ERP) rendszerek, az ügyfélkapcsolati menedzsment (CRM) megoldások rengeteg adat szinte automatikus előállítását teszik lehetővé. A problémát már nem az jelenti, hogy kevés vagy nem megfelelö információk állnak rendelkezésre, hanem gyakran az, hogy túl sok az információ, s ezeket szelektálni, értelmezni, elemezni kellene. Az elmúlt évtized teljesítménymérési „válsága” a mutatók túlburjánzásával jellemezhető, ahol gyakran hiányzik a célok és az eszközök összhangja (Lásd pl. Neely et al., 2004: 3. fejezet). Enélkül pedig nehezen érhető el, hogy a mérés valóban a fejlesztést szolgálja, $s$ ne öncélú adatgyüjtést jelentsen.

Az információbőség a vevői, illetve a szállítói kapcsolatokhoz kötődő információk egy részét is könnyen elérhetővé teszi - gondoljunk csak az említett ERP és CRM rendszerek lehetőségeire, vagy az interneten történő rendelés vagy akár csak böngészés nyomon követésének felhasználhatóságára. Az így gyüjtött információk alapvetően az objektív, mérhető adatok közé tartoznak (pl. rendelési mennyiség, időben történő szállítás stb.). A teljesítmény (és a kapcsolatok) értékelésének a tapasztalatok szerint fontosak a szubjektív, véleményen alapuló elemei is. Ezek begyüjtése gyakran értékelő kérdöívek kitöltetésével történik, melyek terjedésével egy újabb problémába ütközhetünk: az ügyfelek számára unalmassá, fárasztóvá válhat a gyakori zaklatás még az esetleges ösztönzés ellenére is. Mindezek a tendenciák azt jelzik, hogy az információbőség - mely Herbert Simon szerint figyelemszegénységet szül (idézi: Shapiro - Varian, 2000) - korában még nagyobb figyelmet kell arra fordítanunk, hogy a megfelelö, valóban hasznos, fontos tényezőkre figyeljünk. Nem az információk mennyisége, hanem a minősége a lényeg, s a sok információ még nem helyettesíti a kulcstényezők megjelenítését. Fokozottan érvényes ez az üzleti kapcsolatokra is, ahol gyakran nem kiegyensúlyozott a vállalatok figyelme.

\footnotetext{
${ }^{10}$ Részletesebben lásd pl. Sebestyén (2003), in: Chikán - Wimmer (szerk.) (2003).
} 
Válasz az új kihívásokra -új generációs teljesitménymérési megközelitések

A kilencvenes évek második felétöl egyre gyakrabban felmerül az érintettek szélesebb körére kiterjesztett teljesítménymérés igénye. ${ }^{11}$ A teljesítményprizmának, az új generációs teljesítménymérési keretek viszonylag fiatal, de egyre népszerübb eszközének is az érintett alapú megközelítés az alapja. Megalkotói, Andy Neely és munkatársai, a cranfieldi (korábban cambridge-i) teljesítménymenedzsment kutatóközpont tagjai kiemelik, hogy ez „,nem egy elöíró modell, hanem egy segédeszköz a gondolkodáshoz." A keret öt, egymással kapcsolatban álló területet igyekszik integrálni: az érintettek elégedettségét, a hozzájárulásukat, a stratégiákat, a folyamatokat és a képességeket. (Lásd 4. ábra)

\section{4. ábra}

\section{A teljesítményprizma gondolati kerete}

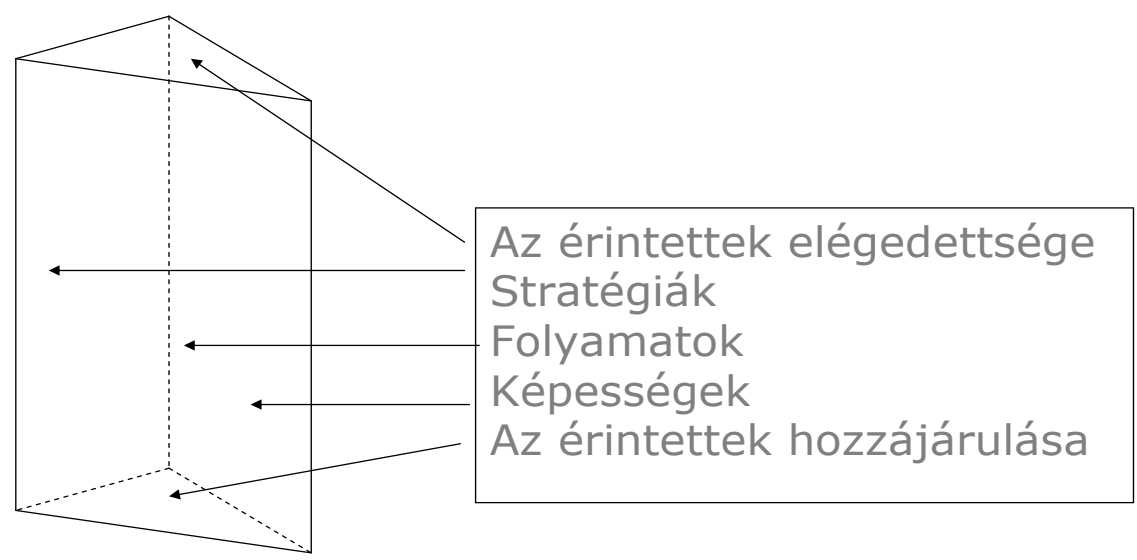

- Kik az érintettjeink, milyen igényeket és elvárásokat támasztanak velünk szemben?

- Milyen igényeket és elvárásokat támasztunk mi az érintettjeinkkel szemben?

- Milyen stratégiákat kell alkalmaznunk az előbbi igények és elvárások kielégítésére?

- Milyen folyamatok segítségével hajthatjuk végre stratégiáinkat?

- Milyen képességekkel (emberekkel, eljárásokkal, technológiával és infrastruktúrával)

működtethetjük hatékonyabban és eredményesebben folyamatainkat?

Forrás: Neely et al. (2004)

A szerzők széles körü példákkal is szolgálnak a nevesített érintettcsoportok (így a tulajdonosok, az ügyfelek, az alkalmazottak, a szállítók, illetve a hatóságok és a helyi közösségek) lehetséges elvárásaival és igényeivel, valamint hozzájárulásukkal kapcsolatban, $\mathrm{s}$ rámutatnak a kapcsolódó teljesítménymérési lehetőségekre és problémákra. $^{12}$

A tendencia tehát - az elméletalkotásban mindenképp, de a vállalati figyelem terén is fellelhető módon - egyre inkább az érintettek szélesebb körére kiterjesztett figyelem, $\mathrm{s}$ annak a felismerése, hogy milyen nagy a jelentősége a kapcsolat kölcsönösségének.

\footnotetext{
${ }^{11}$ Lásd pl. Atkinson et al. (1997).

12 Részletesebben lásd Neely et al. (2004).
} 


\section{Vevői és szállítói kapcsolatok a teljesítménymérésben}

A következőkben azt vizsgáljuk, hogy a vevői, illetve a szállítói kapcsolatok hogyan jelennek meg a teljesítménymérésben: általában mit mérnek, figyelnek ezekhez kötődően a vállalatok, s gyakran milyen lehetőségeket hagynak ki.

Vevöi elégedettség

A vevőkiszolgálás fontossága, s a fogyasztói (vevői/ügyfél) elégedettség fogalma egyre elterjedtebb - legalábbis a deklaráció szintjén. A korábban említett hiányosságok („rések”) ellenére a fogyasztói elégedettség mérésének kiterjedt irodalma, módszertana van. $^{13}$ A fogyasztói elégedettség, illetve hüség mérése nemcsak vállalatok, de tevékenységek, piacok szintjén is történhet. Sőt vannak aggregált, nemzeti elégedettségi indexek is - ezek közül a legrégebbi, a svéd index 1989-ben indult, tehát több mint 15 éves (Hofmeister - Simon - Sajtos, 2003).

Heskett és munkatársai (2003) a vásárlói viselkedés öt fokozatát különböztetik meg, ahol a vevői elégedettség csak az első lépés a kapcsolat fejlődésében. Ennél nagyobb értéket jelent a hüség (visszatérő vásárló). A következő fokozat az elkötelezett vásárló, aki másokkal is közli elégedettségét, majd a termék/szolgáltatás szószólójává (,,apostolává”) váló ügyfél, aki meggyőz másokat is. A felvázolt hierarchia csúcsán a tulajdonossá váló ügyfél került, aki személyes felelősséget, kockázatot is vállal a további sikeres üzletmenetben (im. p. 55).

$\mathrm{Az}$ ügyfelek elégedettségének vizsgálatakor a jelenlegi vevőink elégedettségének szintjét befolyásoló jellemzők mellett a potenciális vevők észlelésének felmérése is fontos. Az előbbi elemei például a termékdesign/minőség/megbízhatóság a használat során, a szolgáltatások (kényelem/gyorsaság/egyszerü felhasználás/pontosság/ a személyzet udvariassága és hozzáértése) és az ár-érték arány. A potenciális ügyfelek észlelésével kapcsolatban hasznos lehet a versenytárs-elemzés (minőség/szolgáltatás/érték), a vevői panaszok vizsgálata (kategóriánként), a jótállási igények, s a visszaküldött, hibás termékek arányának a figyelemmelkísérése.

\section{Szállitóértékelés}

A beszerzés, a logisztika eszköztárának fontos eleme a szállítók kiválasztására, $\mathrm{s}$ rendszeres értékelésére alkalmazott közelítések, módszerek. Ezek az elemek nem feltétlenül épülnek be a teljesítménymérési és kontrollingrendszerbe, de valamilyen formában (ha másként nem, implicit módon) jelen vannak a kapcsolódó döntések hátterében.

A szállítókiválasztás és -értékelés eszköztárához kapcsolódóan felmerül az informális és formalizált elemek szerepének kérdése. Különösen kisebb cégek esetében előfordul, hogy az intuíció, a személyes tapasztalatok szerepe a meghatározó, s nincs formális értékelö rendszer.

További fontos kérdés, hogy mire irányul, s milyen információkra épül az értékelés. Különösen a kiválasztás során alkalmazott előzetes értékelés folyamatában van ennek jelentősége, hiszen a müködő kapcsolat eredménye elvileg már könnyebben mérhetö. Az eszközök széles skálájával találkozhatunk itt is, a pénzügyi adatok bekérésétől és értékelésétől kezdve, a szállítói képességek, kompetenciák értékelésén át, a részletes szállítói auditokig.

\footnotetext{
${ }^{13}$ Részletesen lásd pl. Hofmeister - Simon - Sajtos (2003).
} 
Ha fellapozunk egy logisztikai vagy beszerzési szakkönyvet, a szállítóértékelés módszereit csoportokba sorolják. A kategorizáló módszerek a kiemelt szempontok szerint kategóriákba sorolva minősítik a szállítói teljesítményt. A súlyozott pontszám módszer már konkrét súlyokat rendel a szempontokhoz, s pontértéket a teljesítményhez, így a kialakult pontszám alapján elvileg egyértelmüen rangsorolhatók a beszállítók. A megközelítést tekintve „csúcsmegoldás” a már idézett TCO lényege valamennyi, az adott szállítóval való kapcsolattartásból származó költség számszerüsítése. Alapelv, hogy nem a legalacsonyabb árat, hanem az összességében, minden járulékos költséget, veszteséget, ráfordítást figyelembe véve „legolcsóbb” beszállítót kell választani. A módszer összetettsége nehezíti a gyakorlati bevezetést, de már önmagában a szemléletmód alkalmazása is elöremutató lehet.

Ford és munkatársai (1998) a beszállítói kapcsolatok értékelésének két fő elemét emelik ki: a kapcsolat költségeit és a kapcsolat hasznát. A kapcsolat költsége a közvetlen beszerzési költségekből és a kapcsolat fenntartásának, kezelésének költségeiből tevődik össze. A kapcsolat haszna, előnyei egyrészt költségelőnyökben, másrészt a jövedelemben megjelenő előnyökben nyilvánulhatnak meg. E szemléletmód a szállítói kapcsolatok egy átfogóbb értékelését teszi lehetővé.

A szállítóértékelés kapcsán legalább az utalás szintjén meg kell említenünk a beszerzési/beszállítói portfólió értékelését is. A leggyakoribb kiindulópont a Paretoelemzés alkalmazása, mely a beszállítók koncentrációját vizsgálja. A koncentráció egyszerüsítheti a kapcsolattartást, s az erőviszonyokra, befolyásra is hatással lehet.

Az érem másik oldala

Az előbbiekben láthattuk, hogy a szállítói teljesítmény értékelésére vannak bevált megközelítések, s a vevői elégedettség mérése is egyre inkább a figyelem középpontjába kerül. (Nem hangsúlyozhatjuk elégszer, hogy egy-egy tényező fontosságának felismerése, vagy hangoztatása még nem azonos a felhasználásával, $\mathrm{s}$ beépítésével a teljesítménymérési és teljesítménymenedzsment-rendszerbe. Mindemellett az értékteremtő tényezők felismerése mindenképp kiindulópont azok kezeléséhez s fejlesztéséhez.)

A vevői és a szállítói kapcsolatok mérésénél hipotézésünk szerint megfigyelhető egyfajta egyensúlytalanság. Ez egyrészt a mérés tényére, másrészt a mért, vizsgált tényezőknél a mérés megfelelöségére vonatkozik. Ezt szemlélteti az 5. ábra, példákat is mutatva a lehetséges értékelési eszközökre.

\section{5. ábra}

A mérés eszközei és használatuk az üzleti kapcsolatokban

\begin{tabular}{|c|c|c|}
\hline & $\begin{array}{c}\text { Teljesítménye/ } \\
\text { jövedelmezősége }\end{array}$ & Elégedettsége \\
\hline Ügyfél, vevő & $\begin{array}{c}\stackrel{?}{\text { vevők jövedelmezősége }} \\
\text { vevöérték }\end{array}$ & $\begin{array}{c}\checkmark \\
\text { vevői elégedettség } \\
\text { vevői hüség } \\
\text { vevőmegtartás } \\
\text { vevői érték } \\
\end{array}$ \\
\hline Beszállító & $\begin{array}{c}\checkmark \\
\text { szállítóértékelés } \\
\text { TCO }\end{array}$ & $\begin{array}{l}? \\
\text { szállítói elvárások vs. elégedettség } \\
\text { a vevő értéke a szállitó számára }\end{array}$ \\
\hline
\end{tabular}


$\checkmark$ - gyakran mért tényezők

? - kevéssé mért tényezők

A leggyakoribb problémaforrások a következőkben foglalhatók össze:

- Vizsgáljuk a vevők elégedettségét, de vajon tudjuk-e, melyek számukra a fontos tényezők? (Mit várnak el, mitől lesznek valóban elégedettek?)

- Vizsgáljuk a vevők elégedettségét (jól vagy rosszul), de vajon tudjuk-e, mennyire jók, jövedelmezőek, hasznosak számunkra az ügyfeleink?

- Vizsgáljuk a beszállítók teljesítményét, de vajon az értékelés összhangban van-e stratégiai és müködési céljainkkal?

- Vizsgáljuk a beszállítók teljesítményét (jól vagy rosszul), de vajon tudjuk-e, hogy mi milyen vevői (ügyfelei) vagyunk szállítóinknak? (Mennyire elégedettek velünk, mint vevőkkel a beszállítóink)?

A helyzetet tovább árnyalja, hogy az elégedett vevő hüsége, elkötelezettsége értéket jelent a vállalat számára, tulajdonképpen értékesebbé teszi a vevőt. A vevői érték (a vevő számára nyújtott érték tehát növelheti a vevőértéket (azt az értéket, amit a vevő képvisel a vállalat számára).

Az egyedi vevők értéke mellett fontos a vevői (ügyfél) portfólió értékelése is. Itt nemcsak a jövedelmezőség elemzése lehet fontos, hanem a vevők életciklusa, s az általuk hordozott érték. A hüséges, elkötelezett vevők megszerzéséhez, megtartásához idő kell, s a vevőportfólió elkötelezettség szerinti összetétele is fontos lehet.

Gyakran elfeledett szempont a szállítók/stratégiai partnerek elégedettségének felmérése, tudatos kezelése. Ahogyan a vállalat szállítóit értékeli, hasonlóképpen értékelhetik a vállalatot a vevői. Ennek kulcstényezőit érdemes szem előtt tartani. A 6. ábra a szállítók és a vevők megítélésének néhány szempontját szemlélteti. Minden vállalat vevői s szállítói szerepben is van egyidejüleg az esetek többségében, így a kérdések mindkét irányban feltehetők (s fel is teendők): Hogyan járulnak hozzá ügyfeleink, vevőink, illetve beszállítóink vállalatunk sikeréhez? Hogyan járulunk hozzá vevőként, megrendelőként, illetve beszállítóként, szolgáltatóként üzleti partnereink sikereihez?

\section{6. ábra}

A szállítók és az ügyfelek hozzájárulása

\begin{tabular}{|l|l|}
\hline \multicolumn{1}{|c|}{ A szállítók/stratégiai partnerek hozzájárulása } & \multicolumn{1}{|c|}{ Az ügyfelek hozzájárulása } \\
\hline A stratégiai partnerek hozzájárulása az árbevétel & Vevöjövedelmezőségi elemzés \\
növeléséhez/a költségek csökkentéséhez & Vevői hüség \\
A szállító teljesítményével kapcsolatos panaszok & Teljes vevői érték \\
száma & A megismételt vásárlás értéke \\
Az igényeknek nem megfelelő termékminőség & A jelenlegi vevőkkel folytatott tranzakciók \\
előfordulási gyakorisága & értékének növekedése \\
Az (ígért/igényelt) határidőn túl történő szállítás & A vállalat ajánlására való hajlandóság \\
Az értékesítés után jelentkező termékkel/ & A vevők által tett fejlesztési javaslatok száma/ \\
szolgáltatással kapcsolatos problémák száma & azok végrehajtása \\
Beszállítói hibára visszavezethető garanciális/ & A keresleti előrejelzések pontossága \\
termékfelelősségi igények száma & A számla határidő elött/után történő \\
A szállítóktól származó fejlesztési javaslatok & kiegyenlítésének aránya (Vevőkockázati szint) \\
száma/ ebből az alkalmazásra kerülő javaslatok & \\
száma & \\
A szállítói hozzájárulás észlelt ár/érték aránya & \\
\hline
\end{tabular}


Az előbbi tényezők már nemcsak a partner teljesítményéhez, hanem a kapcsolat jellemzőihez kapcsolódó szempontokat is tartalmaznak. Gunasekaran és munkatársai (2001) az üzleti kapcsolatok értékelésének következő szempontjait fogalmazzák meg: információ-megosztás, együttmüködés a költségcsökkentés érdekében, együttmüködés a minőség és a szolgáltatási színvonal fejlesztése érdekében, a „bevonás” és az együttmüködés a probléma-megoldásban.

Láthattuk, hogy az üzleti kapcsolatok értékelése többtényezős, komplex terület, mely a partnerekkel való kölcsönös viszonyt, az egymás számára nyújtott értékeket, $\mathrm{s}$ ehhez kapcsolódóan az együttmüködés, a kapcsolat jellemzőit is magában foglalja. A gyakorlati törekvés, a kapcsolat értékének egyértelmü meghatározása gyakran csorbát szenved az egyoldalú szemlélet vagy éppen a mérési nehézségek miatt.

\section{Zárszó}

Az üzleti kapcsolatok értékelése és fejlesztésének támogatása során is felmerülnek a teljesítménymérés klasszikus kérdései, miszerint miért, mit, $\mathrm{s}$ hogyan mérünk, $\mathrm{s}$ mindezek után hogyan, mire használjuk az eredményeket.

A kiindulópont mindenképpen a „Miért mérünk?" kérdés megválaszolása, hiszen enélkül öncéllá, s haszontalan kimutatások készítésévé válhat a mérés. A mérés célja mindenképp a folyamatok és a kapcsolatok megértése, s ezt felhasználva fejlesztése, „menedzselése”, kezelése kell, hogy legyen.

A „,Mit mérünk?" kérdésre adott válaszban meg kell fogalmaznunk a fókuszokat, a stratégia megvalósítását támogató célokat, s ügyelni az egyensúlyra. Amint láthattuk, az üzleti kapcsolatok értékelése több szinten, több szempontból történhet: az üzleti partnerek elégedettsége (az üzleti partnerek által észlelt teljesítményünk), elégedettségünk az üzleti partnerekkel (az üzleti partnerek általunk észlelt teljesítménye), a kapcsolat értékelése és a kapcsolati portfolió értékelése egyaránt fontos.

A „Hogyan mérünk?” kérdésre adódó klasszikus lehetőségek például az objektív és szubjektív, a belső és külső információk felhasználása, melyek a kiegyensúlyozottabb képet segíthetik.

A „Hogyan használjuk?” az egyik legkrtikusabb pont. A teljesítménymérés akkor válhat hasznossá, ha valóban visszacsatolást nyújt, a döntéstámogatás, s a fejlesztés támogatója. Mindebben kulcstényező az elvárások kommunikálása, az észlelés/értékelés kommunikálása, s az együttmüködés, fejlesztés szemléletének a középpontba állítása. Az üzleti teljesítménymérés eszköztára akkor szolgálhatja az eredményes és hatékony vállalati müködést, $\mathrm{s}$ a teljesítmény fejlesztését, ha túllép a vállalat határain: a vállalaton belül és határain túl egyaránt segíti a sikert befolyásoló kulcselemek, értékteremtő tényezők megértését és alakítását.

\section{Felhasznált irodalom}

Atkinson, A. A. - Waterhouse, J. H. - Wells, R. B. (1997): A Stakeholder Approach to Strategic Performance Measurement, Sloan Management Review, Spring, pp. 25-37.

Berács József - Sajtos László (2004): A vállalati marketingteljesítmény értékelése, VIII. Ipar- és Vállalatgazdasági Konferencia, Pécs, 2004. október 21-22. In: Gazdasági szerkezet és versenyképesség az EU csatlakozás után - A VIII. Ipar- és Vállalatgazdasági Konferencia előadásai, pp. 62-68. 
Chikán Attila - Demeter Krisztina (szerk.) (1999): Az értékteremtő folyamatok menedzsmentje. Aula Kiadó, Budapest

Chikán Attila - Czakó Erzsébet - Zoltayné Paprika Zita (szerk.) (2002): A vállalati versenyképesség alakulása a globalizálódó magyar gazdaságban, Akadémiai Kiadó, Budapest

Cooper, R. (1996): Costing Techniques to Support Corporate Strategy: Evidences from Japan. Management Accounting Research. No.7. pp. 219-246.

Cross, K. - Lynch, R.(1989): Accounting for Competitive Performance. Journal of Cost Management. Spring. pp. 20-28.

Dixon, J. R. - Nanni, A. J. - Vollmann, T. E. (1990): The New Performance Challenge - Measuring Operations for World Class Competition. Dow Jones-Irwin, Homewood

Ellram, L. M. (1995): Activity-Based Costing and Total Cost of Ownership: A Critical Linkage. Journal of Cost Management. Winter. pp. 22-29.

Ford, David et al. (1998): Managing Business Relationships. John Wiley \& Sons, New York

Gunasekaran, A. - Patel, C. - Tirtiroglu, E. (2001): Performance Measures and Metrics in a Supply Chain Environment. International Journal of Operations and Production Management. Vol. 21. No. 1-2. pp.71-87.

Heskett, James L. - Sasser, W. Earl Jr. - Schlesinger, Leonard A. (2003): The Value Profit Chain - Treat Employees Like Customers and Customers Like Employees. The Free Press, New York

Hofmeister Tóth Ágnes - Simon Judit - Sajtos László (2003): A fogyasztói elégedettség. Alinea Kiadó, Budapest

Juhász Péter (2005): Az üzleti kapcsolatok pénzügyi értékelése. Vezetéstudomány, 5. SZ.

Kaplan, Robert S. - Atkinson, Anthony A. (2003): Vezetői üzleti gazdaságtan - Haladó vezetői számvitel. Panem-Business Kft., Budapest

Kaplan, Robert S. - Cooper, Robin (1998): Cost \& Effect. Using Integrated Cost Systems to Drive Profotability and Performance, Harvard Business School Press. Magyarul megjelent: Költség \& Hatás - Integrált költségszámítási rendszerek: az eredményes vállalati müködés alapjai, Panem - IFUA Horváth \& Partner, 2001, Budapest

Kaplan, Robert S. - Norton, David P. (1998): Balanced Scorecard - Kiegyensúlyozott mutatószám-rendszer. Eszköz, ami mozgásba hozza a stratégiát. Közgazdasági és Jogi Könyvkiadó, Budapest

Kraljic, Peter (1983): Purchasing must become supply management. Harvard Business Review, 61, September-October, pp. 109-117.

Mandják Tibor - Wimmer Ágnes (2002): Business-relationships and value creation. In: „Value and entreprise” congress. Bordeaux Business School, Bordeaux, április 25-26. (konferencia-CD) 
Neely, Andy-Adams - Chris-Kennerley, Mike (2004): Teljesítményprizma. Alinea Kiadó, Budapest

Pecze Krisztina (2005): Az üzleti kapcsolatok értékteremtő szerepének vizsgálata stratégiai nézőpontból, Vezetéstudomány, 5. sz.

Schmenner, Roger W. - Vollmann, Thomas E. (1994): Performance Measures: Gaps, False Alarms and „Usual Suspects”, International Journal of Operations \& Production Management, Vol. 14. No. 12. pp. 58-69.

Sebestyén László (2003): AZ EFQM és a nemzeti minőségi díjak. in: Chikán AttilaWimmer Ágnes (szerk.) (2003): Üzleti fogalomtár. Alinea Kiadó, Budapest

Shapiro, Carl - Varian, Hal R. (2000): Az információ uralma - A digitális világ gazdaságtana. Geomédia Kiadó, Budapest

Wimmer Ágnes - Mandják Tibor (2003): Az üzleti kapcsolatok, mint értékteremtő tényezők? Műhelytanulmány. Budapesti Közgazdaságtudományi és Államigazgatási Egyetem, Vállalatgazdaságtan tanszék.

Wimmer Ágnes (2002): Az üzleti teljesítmény mérése és menedzsmentje, Jegyzet, Budapesti Közgazdaságtudományi és Államigazgatási Egyetem Vállalatgazdaságtan tanszék.

Wimmer Ágnes (2004): Üzleti teljesítménymérés az értékteremtés szolgálatában, Vezetéstudomány, XXXV. évf. (2004) 9. szám, pp. 2-11. 